\title{
EFFECT OF PHOTOPERIODS MANIPULATION ON GROWTH AND SOME REPRODUCTIVE ACTIVITIES OF NILE TILAPIA (Oreochromis niloticus)
}

\author{
Nourhan H. Ahmed ${ }^{1 *}$, A.H. Daader ${ }^{1}$, A.A. El-Darawany ${ }^{1}$, A.M. Abdine ${ }^{1}$ and M.E. Farag $^{2}$ \\ 1. Anim. Prod. Dept., Fac. Agric., Zagazig Univ., Egypt \\ 2. Cent. Lab. Aquac. Res., (CLAR), Agricu. Res. Cent. (ARC), Agric. Min., Egypt
}

\begin{abstract}
The effect of Photoperiod manipulation on growth and some aspects of reproductive performance in Nile tilapia (Oreochromis niloticus) was studied at Animal Production Department, Faculty of Agriculture. The experimental work was conducted at Central Laboratory for Aquaculture Research Center, Ministry of Agriculture, Egypt . Ninety females and Ninety males Tilapia fish $(50 \pm 5 \mathrm{~g})$ each was reared in aquaria of $150 \times 50 \times 50 \mathrm{~cm}$ and treated with three different photoperiods: $18 \mathrm{~L}: 6 \mathrm{D}, 6 \mathrm{~L}$ : 18 D, and natural photoperiod 12 L: 12 D (L, Light; D, Dark). Each treatment consists of 30 males and 30 females which were divided into three replicates. In whole experimental period which lasted for 6 months, other environmental factors were maintained at constant level like, light intensity (500 Lux), water temperature $\left(28^{\circ} \mathrm{C}\right), \mathrm{pH}(9)$ and dissolved oxygen $(6 \mathrm{mg} / \mathrm{l})$. Under these conditions and treatments females and males were weighed and the ovary weight, egg weight, egg number, egg diameter, spawning periodicity and sperm count were recorded. The results showed an increase in male and female weights with increasing time and exposure to photoperiod. Also, ovary weight, egg weight, egg number, egg diameter have the same trend. Long photoperiodic exposure has positive effect on spawning periodicity of Nile Tilapia. The final weights of females and males after six months were significantly higher in L 18:6 D than other light treatments. Egg diameter, final egg number per female, and egg weight were increased significantly with increasing photoperiod. Also, the average final sperm count per male in different light schedules was significant. Long photoperiodic exposure has positive effect on (spawning periodicity) mean time interval until first spawn and mean ISI (inter-spawninterval) in different light periods were enhanced in longer photoperiod than other treatments .The final average serum estradiol in female and final serum testosterone in males are in favor of longer photoperiods than short or natural photoperiod. It could be concluded that growth and reproduction performance in $O$. niloticus can be improved by exposing Nile Tilapia to 18 hours light: 6 hours dark and water temperature of $28^{\circ} \mathrm{C}$ and $\mathrm{pH} 9$.
\end{abstract}

Key words: Photoperiods manipulation, reproductive activits, Nile Tilapia, spawning periodicity.

\section{INTRODUCTION}

Aquaculture has been growing steadily in recent times as an excellent source of highquality protein (Krishen et al., 2009). Researchers focused on Nile tilapia because of its quick reproduction rate, tolerance to hard environments endurance to disease and the possibility to be cultured under diverse farming systems (Yosef, 2009; Soto-Zarazúa et al., 2010).

\footnotetext{
* Corresponding author: Tel. : +201280971402

E-mail address: mto252000@yahoo.com
}

Female Tilapia have individual patterns of ovarian development so that in breeding populations they tend to spawn asynchronously every 3 to 4 weeks, depending upon environmental conditions (Coward and Bromage, 2000). Female tilapia tends to mature and reproduce early at small size before reaching market size (Longalong et al., 1999; and Lutz et al., 2003). The maturation process involves significant changes in teleosts 
including inhibition of growth mechanism (Gines et al., 2003). Tilapia species tend to sacrifice growth to maintain reproductive capacity (Coward and Bromage, 1999) and have also been reported to exhibit tremendous plasticity in growth and maturation (Turner and Robinson, 2000). In physiological terms, early sexual maturity results in reduced growth and consequently poor feed conversion performances. In economic terms, this phenomenon means higher feed costs and lower profitability for tilapia enterprises. Photoperiod could be used as a powerful environmental tool for broodstock management and increasing somatic growth of Nile tilapia (Campos-Mendoza et al., 2004 ; Sawhney and Gandotra, 2010).

Long photoperiod treatments either improve food-processing efficiency directly or suppress sexual maturation thus, redirecting energy from gonadal development to somatic growth (Gines et al., 2004). Onumah et al., 2010 reported that extended photoperiod increase growth rate without affecting other performance traits (egg qualities and fecundity).

Major environmental factors involved in cueing reproductive activity are temperature and photoperiod (Ballarin and Hatton, 1979; LoweMcConnell, 1979; Eyeson, 1983 ; Emit et al., 1989). Bhujel (2000) has reported that photoperiod and light intensity might play an important role in controlling reproduction. Ridha and Cruz (2000) reported that longer and brighter days (18L: 6D with 2500 lux) produced more fry and improved spawning synchrony in Nile tilapia compared with short day and low light intensity (500 lux), also they reported that the degree of spawning synchrony and percentage of the sac and swim-up fry stages were significantly higher in the 2500 lux/18 hr., treatment than in the other treatments. Under the conditions tested, seed production and spawning synchrony in the Nile tilapia may be improved by subjecting breeders to a light intensity of 2500 lux and a photoperiod of 18 hr., day ${ }^{-1}$.

The majority of the studies deals with the impact of long-day photoperiod on growth and reproduction in tilapia were carried out on the earlier stages of fish development (fries or fingerlings), and few were focused on late stage. Boeuf and Le Bail (1999) have reported that receptivity of fish to light profoundly changes according to species and development status.

In addition it was reported (Bromage et al., 2001) that using photoperiodic manipulation produce sufficient numbers of eggs and fry at desired times and thereby ensure all year round production of rainbow trout.

The purpose of the present study was to investigate the effects of photoperiod on growth and reproductive performance of Oreochromis niloticus at late stages of development. Also ensuring the possibility of obtaining eggs and fries at desired time of the year.

\section{MATERIALS AND METHODS}

The study was carried out at Animal Production Department, Faculty of Agriculture and the experimental work was conducted in Central Laboratory Aquaculture Research (CLAR), Abbassa, Abou Hamade District, Sharkia Governorate, Egypt. The experiment lasts for 6 months from March till September 2012.

\section{Experimental Design}

A number of 180 Nile tilapia (Orechromis niloticus) with average $50 \pm 5 \mathrm{~g}$ body weight (90 males and 90 females) were reared in 9 aquaria of $150 \times 50 \times 50 \mathrm{~cm}$ under three different photoperiod treatments, long day (18 L: $6 \mathrm{D})$, short day (6 L: $18 \mathrm{D})$, and natural photoperiod (12 L: 12 D) (L, Light; D, Dark). Each treatment consists of 3 aquaria and 30 males and 30 females. 3 aquaria under a natural photoperiod and 6 aquaria were provided with lampe light intensity 500 Lux (controlled by 24 hr., timers), lab (window and door) were covered by black vinyl sheets to provide complete darkness. In whole experimental interval other environmental factors were maintained at constant level like; light intensity (500 Lux). Water temperature was $\left(28^{\circ} \mathrm{C}\right)$ controlled by thermostatically-controlled water heaters, dissolved oxygen and $\mathrm{pH}$ were maintained at $6 \mathrm{mg}$ and 9 , respectively.

Fish were fed twice daily with commercial pelleted feed $35 \%$ protein at rate $3 \%$ from body weight. Settling tanks were cleaned twice in weak concomitant with a $10-20 \%$ water change. 
In female: body weight, ovary weight, egg production (number, weight and diameter), spawning periodicity, gonad index, fertilization rate, hatching rate and hormonal profile of testosterone and estradiol were estimated at the beginning of experiment, after 3 and 6 months of treatments.

In male: body weight, sperm count and hormonal profile of testosterone and estradiol at the same former periods were determined.

\section{Experimental Procedures}

\section{Growth performance}

Growth performance was measured by weighing the fish individually (males and females) at the beginning of experiment and at three and six months using an electronic balance.

\section{Reproductive performance}

\section{Spawning periodicity}

Spawning activity was recorded for each fish, estimates of spawning periodicity (interspawn-interval and mean day's elapsed spawn-1) were determined as:

ISI (inter-spawn-interval) based upon completed reproductive cycles of repeat spawning fish only, i.e., the time elapsed from one spawn to the next.

\section{Egg number}

The eggs were placed in a $0.9 \%$ saline solution and were counted.

\section{Total egg weight}

Mean egg dry weight was determined by placing eggs on filter paper for 2 minutes then weighed on electronic balance.

\section{Single egg weight}

Mean single egg weight was determined by dividing total egg weight on egg number.

\section{Egg diameters (mm)}

Since eggs are ellipsoid-shaped, both axes (long and short) were measured under a calibrated binocular microscope in order to calculate mean egg diameter [(length + width)/2] according to (Coward et al., 1998).

\section{Fertilization and hatching rate}

Fertilized eggs in the buccal cavity for each fish were collected and the percentage of fertilization and hatching rate were estimated according to Gheyas et al. (2001) as follows:

Fertilization rate $(\%)=$ number of fertilized eggs/ total number of eggs x100,then eggs were removed to the spawning funned four days after fertilization the larvae were removed to tanks to be counted to determine the hatching rate.

Hatching rate $(\%)=$ (number of hatched eggs/ total number of fertilized eggs) $\times 100$

\section{Gonads index}

Gonads were removed from three females of each treatment and Gonado somatic index (GSI) was calculated as gonad weight/total body weight $\times 100$.

\section{Sperm count in males}

Milt was collected from males by massaging the ventral part over the gonads and at the same time collecting the sperm with a pipette and total sperm number of each individual was calculated with a Bürker's cell hemocytometer. Sperm concentration is expressed as the number of spermatozoa per milliliter.

\section{Testosterone and estradiol hormone assay}

Blood was collected from males and females and the serum levels of Testosterone and Estradiol concentration were assayed at zero time and after three and six months of treatment. Regarding to estradiol hormone $(\mathrm{Pg} / \mathrm{ml})$, the calbiotech-Inc E2 Estradiol kits was based on the principle competitive binding between E2 in the test specimen and E2 Estradiol enzyme conjugated for a constant amount of antiEstradiol polyclonal antibody. A standard curve was obtained by plotting the concentration of the standard versus the absorbance (Gore-langton et al., 1988).

The testosterone $(\mathrm{ng} / \mathrm{ml})$ assay is based on the principle of competitive binding between testosterone in the test specimen and testosterone-HRP conjugate for a constant amount of mouse and anti-testosterone, the color development was stopped with the addition of stop solution, and the absorbance is measured spectrophotometrically at $450 \mathrm{~mm}$ (Chen et al. 1991). 


\section{Statistical Analysis}

The obtained data of fish were subjected to one-way ANOVA. Differences between means were tested at the $5 \%$ probability level using Duncan test (Duncan, 1955). All the statistical analyses was done using SPSS program version 10 (SPSS, Richmond, USA) as described by Dytham (1999) according to the following statistical model.

Where:

$$
Y i j=M+T i+S j+e i j
$$

Yij is an observation, $\mathrm{M}$ is the overall mean, $\mathrm{T}$ is the fixed effect of treatment level ( $\mathrm{I}=1,2$ and 3$), \mathrm{S}$ is fixed effect of time $(\mathrm{j}=1$,2and3), and eij is the random error.

\section{RESULTS}

\section{Growth Performance}

The results concerning the effects of different light schedules on growth of both females and males of Nile tilapia are presented in Table 1. It could be noticed that there were no significant differences in fish weight among different treatment groups at the beginning of study. After 6 months of treatment, the differences in final body weight of females and males were statistically significant $(\mathrm{P}>0.05)$ being the highest at $18 \mathrm{~L}$ : $6 \mathrm{D}$ light regime and the lowest at $6 \mathrm{~L}$ : $18 \mathrm{D}$ light regime. At three months of treatment the same trend was noticed. It could be also noted that at each light schedule, males and females weights, naturally increase significantly as the age progresses up to 6 months experimental periods.

\section{Reproductive Performance}

The average ovary weight as affected by different light regimes is presented in Table (2). The results show a significant effect for these light treatments on ovary weight, with the highest values after 6 months of (18 L: 6 D) light regime. After 3 months, the same trend was also observed. Within each treatment, the values of studied character also increased significantly as experimental period progresses.

The results in Table 3 show that the initial total egg weight (TEW) and single egg weight
(SEW) in different light periods were not affected significantly, whereas the final weight was significantly affected, being the lowest $(\mathrm{P}<0.05)$ at $6 \mathrm{~L}$ : $18 \mathrm{D}$ light regime and the highest at $18 \mathrm{~L}: 6 \mathrm{D}$.

The egg diameter of treated females (Table 4) showed significant $(\mathrm{P}<0.05)$ differences due to exposure to different light schedule at both 3 and 6 months of treatment. The (18L : 6D) schedule was the highest, while 6L: 18D was the lowest in terms of egg diameter of treated females. Similar trend in egg diameter was found for egg number. The egg number increased significantly under long day treatment.

Sperm count per male (Table 5) was significantly $(\mathrm{P}<0.05)$ affected with different treatments of light regime. The $18 \mathrm{~L}: 6 \mathrm{D}$ was the most superior, while 6L: 18D light regime resulted in the least sperm count values, this was observed at 3 and 6 months of treatment.

Table 6 reveals that the mean time interval until first spawns (day) was significantly shorter under $18 \mathrm{~L}$ : $6 \mathrm{D}$ than other treatments. There were significant differences detected when comparing inter-spawning-interval (ISI) among different photoperiods, the longest ISI was found in the $6 \mathrm{~L}$ : $18 \mathrm{D}$ treatment. The $18 \mathrm{~L}$ : $6 \mathrm{D}$ photoperiod produced the highest values of Gonado somatic index, fertilization rate, hatching rate and survival rate than the other treatments. The differences were significant among all treatments only for GSI. and between long and short day light for the rest characters (Table 6).

Testosterone hormone in male fish showed that the significantly $(\mathrm{P}<0.05)$ highest and lowest levels were noticed after 3 and 6 months of $18 \mathrm{~L}$ : $6 \mathrm{D}$ and $6 \mathrm{~L}$ : $18 \mathrm{D}$ lighting regimes, respectively. The natural lighting took a moderate situation between the two former regimes, where the testosterone hormone in female fish showed another pattern, hence for unknown reasons it showed the highest level at $6 \mathrm{~L}$ : $18 \mathrm{D}$ system, and the lowest was at $18 \mathrm{~L}: 6$ D system.

Estradiol hormone assay in males and females fish (Table 8) showed that in males, the highest values of hormone were noticed after 3 and 6 months of treatment with 6L: 18D regime. 
Table1. Average females and males weight (g) of Nile Tilapia (Oreochromis niloticus) as affected by different light regimes during experimental periods

\begin{tabular}{|c|c|c|c|c|c|c|}
\hline & \multirow[t]{2}{*}{ Time (month) } & \multicolumn{3}{|c|}{ Light regime } & \multirow[t]{2}{*}{ F value } & \multirow[t]{2}{*}{$P$ value } \\
\hline & & 18L:6D & 6L:18D & Natural & & \\
\hline \multirow{4}{*}{ 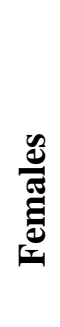 } & Initial female weight & $50.96^{\mathrm{az}} \pm 3.00$ & $50.00^{\mathrm{az}} \pm 0.35$ & $50.16^{\mathrm{az}} \pm 0.46$ & \multirow{3}{*}{16.12} & \multirow{3}{*}{0.155} \\
\hline & After 3 months & $82.20^{\mathrm{ay}} \pm 0.71$ & $72.46^{\mathrm{by}} \pm 2.24$ & $80.63^{\mathrm{ay}} \pm 0.84$ & & \\
\hline & After 6 months & $117.33^{\mathrm{ax}} \pm 2.34$ & $88.11^{\mathrm{cx}} \pm 7.86$ & $106.66^{\mathrm{bx}} \pm 3.50$ & & \\
\hline & F value & & 6.62 & & \multirow{7}{*}{10.06} & \multirow{7}{*}{0.194} \\
\hline \multirow{6}{*}{$\frac{\frac{\mathscr{e}}{\tilde{J}}}{\sum^{\frac{\pi}{2}}}$} & $P$ value & & 0.235 & & & \\
\hline & Initial male weight & $54.70^{\mathrm{az}} \pm 0.565$ & $55.9^{\mathrm{az}} \pm 2.04$ & $56.60^{\mathrm{az}} \pm 0.83$ & & \\
\hline & After 3 months & $83.40^{\mathrm{ay}} \pm 1.00$ & $73.43^{\mathrm{cy}} \pm 2.06$ & $80.63^{\text {by }} \pm 0.83$ & & \\
\hline & After 6 months & $119.66^{\mathrm{ax}} \pm 2.17$ & $92.00^{\mathrm{bx}} \pm 2.06$ & $116.33^{\mathrm{ax}} \pm 1.58$ & & \\
\hline & F value & & 3.39 & & & \\
\hline & $P$ value & & 0.316 & & & \\
\hline
\end{tabular}

Means bearing the same letters within the same row (a-c) or column (x-z) are not significantly (P>0.05) different.

Table 2. The ovaries weight (g) of female Nile tilapia (Oreochromis niloticus) as affected by different light regimes during experimental period

\begin{tabular}{lccccc}
\hline Time (month) & 18L:6D & 6L:18D & Natural & F value & P value \\
\hline Initial ovary weight & $0.51^{\mathrm{az}} \pm 0.03$ & $0.48^{\mathrm{az}} \pm 0.03$ & $0.47^{\mathrm{az}} \pm 0.04$ & & \\
After 3 months & $1.23^{\mathrm{ay}} \pm 0.03$ & $0.88^{\mathrm{cy}} \pm 0.11$ & $1.166^{\mathrm{by}} \pm 0.02$ & $106.3^{* * *}$ & 0.003 \\
After 6 months & $1.76^{\mathrm{ax}} \pm 0.03$ & $1.45^{\mathrm{cx}} \pm 0.07$ & $1.67^{\mathrm{bx}} \pm 0.02$ & & \\
F value & & 4.59 & & & \\
P value & & 0.09 & & & \\
\hline
\end{tabular}

Means bearing the same letters within the same row (a-c) or column (x-z) are not significantly (P>0.05) different. 
Table 3. Average total female egg weight (g) and single egg weight (mg) of Nile tilapia (Oreochromis niloticus) as affected by different light regimes at different experimental periods

\begin{tabular}{|c|c|c|c|c|c|c|c|}
\hline & & Time (month) & & ight regime & & F value & P value \\
\hline & & & 18L:6D & 6L:18D & Natural & & \\
\hline & & Initial egg weight per female & $0.49^{\mathrm{az}} \pm 0.05$ & $0.49^{\mathrm{az}} \pm 0.06$ & $0.50^{\mathrm{az}} \pm 0.07$ & & \\
\hline 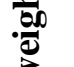 & $\frac{\mathscr{\sigma}}{\pi}$ & After 3 months & $0.77^{\mathrm{ay}} \pm 0.06$ & $0.59^{\text {by }} \pm 0.07$ & $0.72^{\mathrm{ay}} \pm 0.04$ & $22.748 * * *$ & 0.006 \\
\hline $\begin{array}{l}3 \\
00 \\
00 \\
0\end{array}$ & & After 6 months & $1.53^{\mathrm{ax}} \pm 0.04$ & $0.97^{\mathrm{cx}} \pm 0.03$ & $1.34^{\mathrm{bx}} \pm 0.04$ & & \\
\hline$\frac{0}{5}$ & & F value & & 1.769 & & & \\
\hline$\stackrel{0}{H}$ & & $P$ value & & 0.282 & & & \\
\hline 해 & & $\begin{array}{l}\text { Initial single } \\
\text { egg weight }\end{array}$ & $4.67^{\mathrm{az}} \pm 0.23$ & $4.83^{\mathrm{ay}} \pm 0.16$ & $4.86^{\mathrm{az}} \pm 0.1$ & 807 & 07 \\
\hline$\sum_{0}^{0}$ & & After 3 months & $6.34^{\mathrm{ay}} \pm 0.09$ & $5.33^{\mathrm{cy}} \pm 0.18$ & $6.00^{\text {by }} \pm 0.15$ & 2.07 & 0.241 \\
\hline ن & & After 6 months & $6.60^{\mathrm{ax}} \pm 0.11$ & $5.96^{\mathrm{bx}} \pm 0.15$ & $6.40^{\mathrm{ax}} \pm 0.12$ & & \\
\hline$\stackrel{D}{=}$ & & F value & & 4.364 & & & \\
\hline & & $P$ value & & 0.09 & & & \\
\hline
\end{tabular}

Means bearing the same letters within the same row (a-c) or column (x-z) are not significantly (P>0.05) different.

Table 4. Average egg diameter $(\mathrm{mm})$ and egg number of female Nile tilapia (Oreochromis niloticus) in different light regimes

\begin{tabular}{|c|c|c|c|c|c|c|}
\hline & \multirow[t]{2}{*}{ Time (month) } & \multicolumn{3}{|c|}{ Light regime } & \multirow[t]{2}{*}{ F value } & \multirow[t]{2}{*}{ P value } \\
\hline & & 18L:6D & 6L:18D & Natural & & \\
\hline \multirow{5}{*}{ 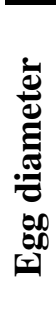 } & Initial egg diameter & $1.44^{\mathrm{ay}} \pm 0.03$ & $1.405^{\mathrm{az}} \pm 0.01$ & $1.42^{\mathrm{az}} \pm 0.03$ & & \\
\hline & After 3 months & $1.77^{\mathrm{ay}} \pm 0.03$ & $1.57^{\mathrm{cy}} \pm 0.02$ & $1.71^{\text {by }} \pm 0.02$ & $361 * *$ & 0.03 \\
\hline & After 6 months & $1.89^{\mathrm{ax}} \pm 0.02$ & $1.66^{\mathrm{cx}} \pm 0.03$ & $1.81^{\mathrm{bx}} \pm 0.03$ & & \\
\hline & F value & & $841^{* *}$ & & & \\
\hline & $P$ value & & 0.02 & & & \\
\hline \multirow{5}{*}{ 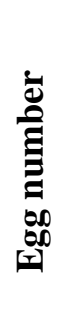 } & Initial egg number & $60.6^{0 \mathrm{az}} \pm 2.78$ & $62.33^{\mathrm{az}} \pm 3.00$ & $64.22^{\mathrm{az}} \pm 2.43$ & & \\
\hline & After 3 months & $133.00^{\mathrm{ay}} \pm 4.33$ & $90.33^{\mathrm{cy}} \pm 2.0$ & $124.00^{\text {by }} \pm 2.45$ & $41.02 * * *$ & 0.002 \\
\hline & After 6 months & $226.00^{\mathrm{ax}} \pm 5.14$ & $168.00^{\mathrm{cx}} \pm 4.06$ & $205^{.00 \mathrm{bx}} \pm 6.12$ & & \\
\hline & F value & & 1.7 & & & \\
\hline & P value & & 0.291 & & & \\
\hline
\end{tabular}

Means bearing the same letters within the same row (a-c) or column (x-z) are not significantly (P>0.05) different. 
Table 5. Average sperm count per male (sperm/lx10 ${ }^{12}$ ) of Nile Tilapia (Oreochromis niloticus) in different light regimes

\begin{tabular}{lccccc}
\hline Time (month) & \multicolumn{5}{c}{ Light regime } \\
\cline { 2 - 6 } & 18L:6D & $\mathbf{6 L : 1 8 D}$ & Natural & F value & P value \\
\hline Initial sperm count & $171.50^{\mathrm{az}}+5.82$ & $178.50^{\mathrm{az}}+7.58$ & $172.5^{0 \mathrm{az}}+4.34$ & & \\
After 3 months & $249.00^{\mathrm{ay}}+3.46$ & $188.50^{\mathrm{cy}}+4.33$ & $210.40^{\mathrm{by}}+4.03$ & $19.62^{* * *}$ & 0.008 \\
After 6 months & $261.00^{\mathrm{ax}}+4.15$ & $197.20^{\mathrm{cx}}+15.83$ & $237.70^{\mathrm{bx}}+4.42$ & & \\
F value & & $6.54^{*}$ & & & \\
P value & & 0.05 & & & \\
\hline
\end{tabular}

Means bearing the same letters within the same row (a-c) or column (x-z) are not significantly (P>0.05) different.

Table 6. Some reproductive parameters of female Nile tilapia (Oreochromis niloticus) in different light regimes

\begin{tabular}{lccc}
\hline Item & 18L:6D & 6L:18D & Natural \\
\hline Mean time interval until first spawn (day) & $18.9^{0 \mathrm{c}} \pm 0.5$ & $25.70^{\mathrm{a}} \pm 1.3$ & $22.5^{0 \mathrm{~b}} \pm 1.1$ \\
Mean ISI (day) (inter-spawn-interval) & $21.70^{\mathrm{c}} \pm 1.2$ & $31.20^{\mathrm{a}} \pm 2.1$ & $26.50^{\mathrm{b}} \pm 1.3$ \\
GSI (\%) & $1.87^{\mathrm{a}} \pm 0.2$ & $0.92^{\mathrm{c}} \pm 0.02$ & $1.650^{\mathrm{b}} \pm 0.02$ \\
Fertilization rate (\%) & $98.1^{0 \mathrm{a}} \pm 2.2$ & $78.2^{0 \mathrm{~b}} \pm 4.2$ & $99.20^{\mathrm{a}} \pm 5.8$ \\
Hatching rate (\%) & $85.40^{\mathrm{a}} \pm 1.7$ & $69.40^{\mathrm{b}} \pm 1.6$ & $80.6^{0 \mathrm{a}} \pm 3.6$ \\
Survival rate (\%) & $83.40^{\mathrm{a}} \pm 1.4$ & $60.20^{\mathrm{b}} \pm 2.1$ & $80.10^{\mathrm{a}} \pm 4.2$ \\
\hline
\end{tabular}

Means bearing the same letters $(\mathrm{a}-\mathrm{c})$ within the same row are not significant $(\mathrm{P}>0.05)$. 
Table 7. Average serum testosterone $(\mathrm{ng} / \mathrm{ml})$ of males and females Nile tilapia (Oreochromis niloticus) in different light regimes

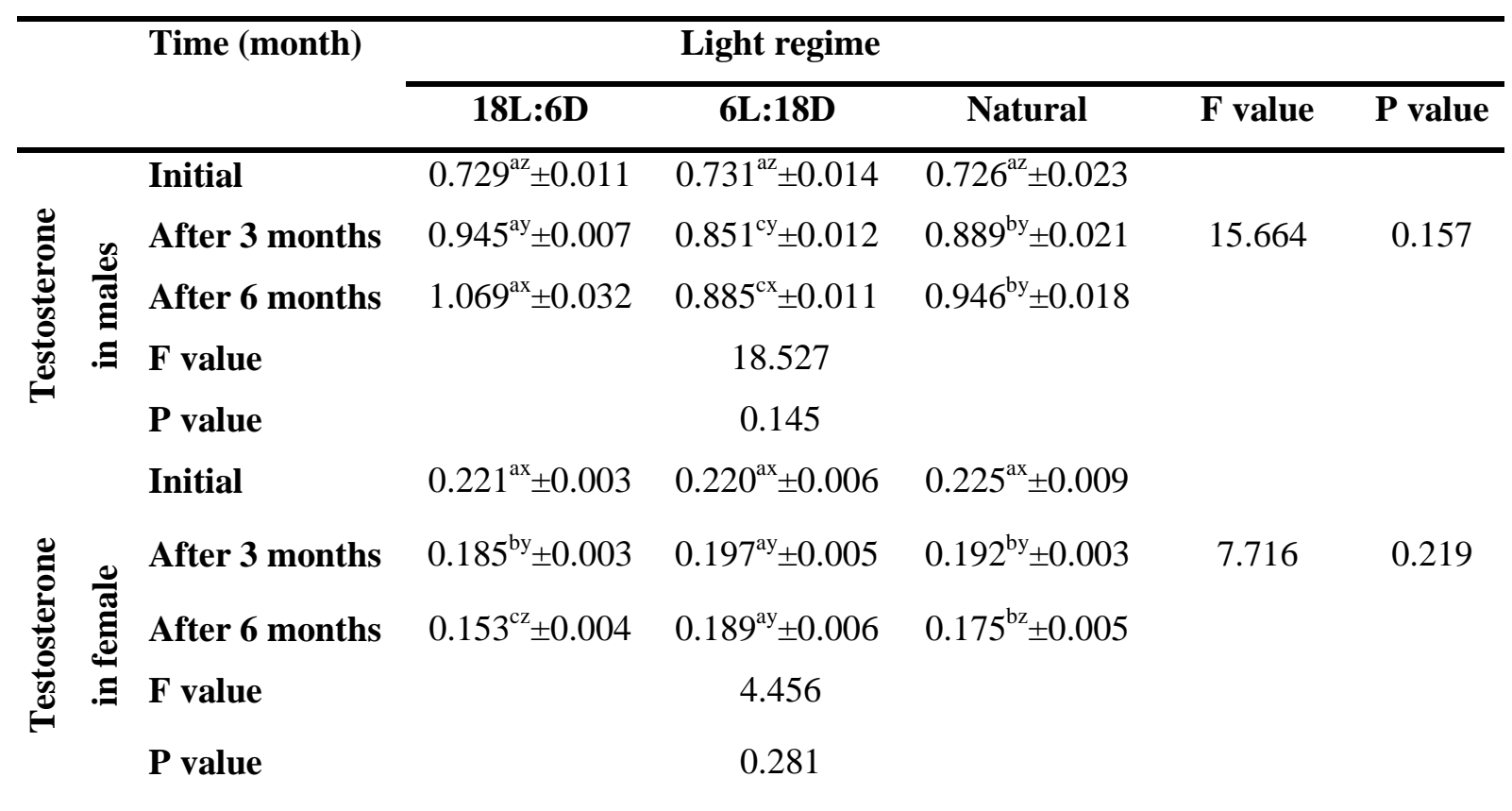

Means bearing the same letters within the same row (a-c) or column (x-z) are not significantly $(\mathrm{P}>0.05)$ different.

Table 8. Average serum estradiol (Pg/ml) in male and females Nile tilapia (Oreochromis niloticus) in different light regimes

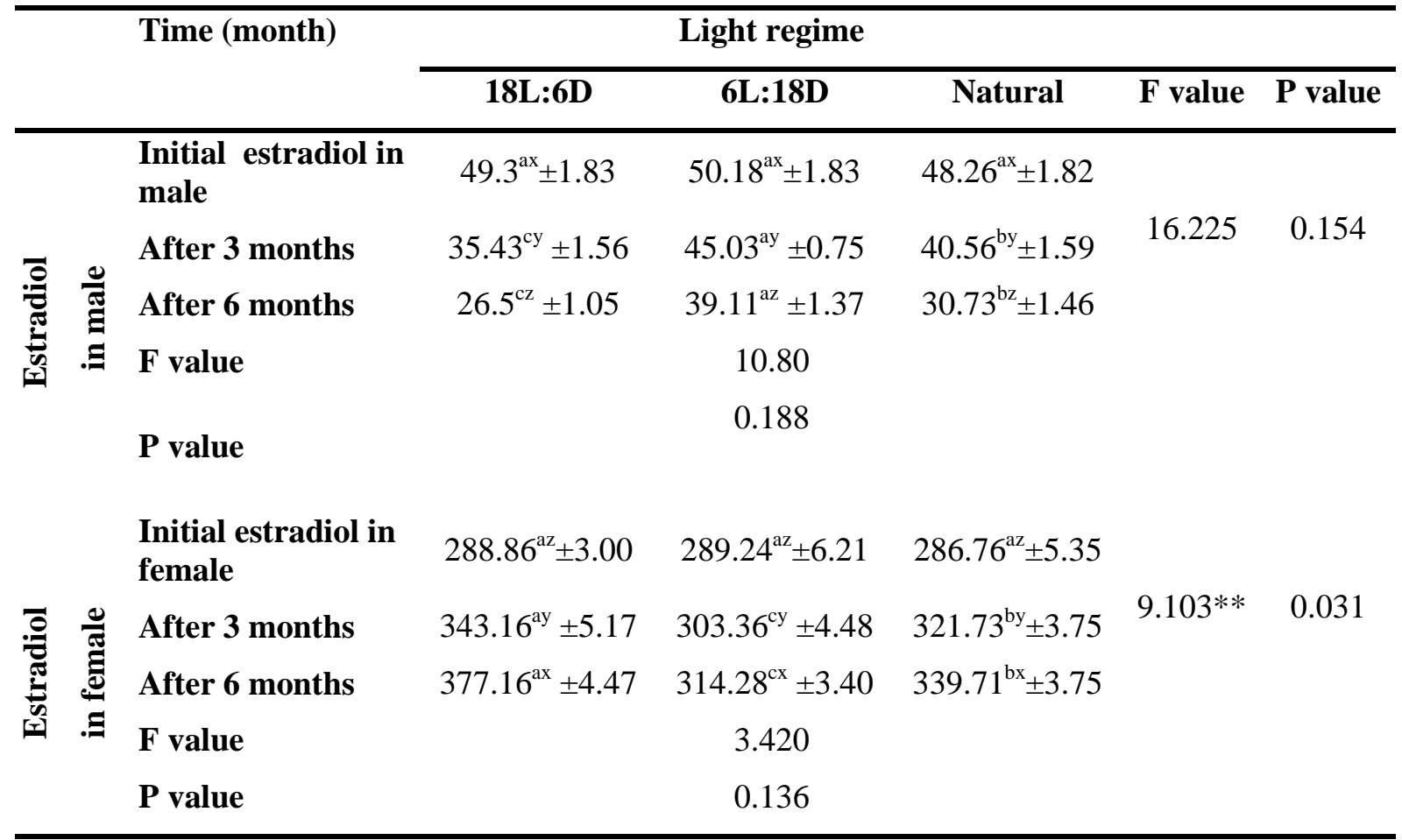

Means bearing the same letters within the same row (a-c) or column (x-z) are not significantly ( $\mathrm{P}>0.05)$ different. 
In contrary, estradiol values, in females, were the highest $(\mathrm{P}<0.05)$ under $18 \mathrm{~L}: 6 \mathrm{D}$ and the lowest at $6 \mathrm{~L}: 18 \mathrm{D}$ at 3 and 6 months of light treatment. Under the condition of this work, it could be mentioned that, response of both males and females, in terms of sex steroid hormones, to the above mentioned light system is different.

In other words, it is worth noticing that testosterone and estradiol hormones in males and females, respectively responded positively to long day, while testosterone in females and estradiol in males responded more clearly to short day but not long day.

\section{DISCUSSION}

In the present study, a significant increase in females and males weight in longer photoperiod subjected group (18L: 6D) was reported. These results agree with Gines et al. (2004), Biswas et al. (2008), El-Sayed and Kawanna (2004), Rad et al. (2006), Cruz and Brown (2009), Onumah et al. (2010), Ali and El-Feky (2013) and Elsbaay (2013). It was found that the increased growth rate of fishes at longer photoperiod is believed to be attributed to improved appetite, increased feed intake, higher feed efficiency, higher digestibility and suppressed sexual maturation. (Gines et al. 2004; Biswas et al. 2005) Energy metabolism and somatic growth in teleosts are regulated by a complex endocrine system that directly or indirectly involves a variety of hormones. Central in the hormonal control of growth is the GH-IGF-I axis. GH and IGF-I have both metabolic and growthpromoting functions. Additionally, Biswas et al. (2008) noted an increase in body protein and lipid with increasing photoperiod, that may be attributed to the protein being deposited in the body to enhance growth.

On the other hand, the growth and metabolic rates of several other species were not significantly affected by photoperiods (Hallaraker et al., 1995). According to the results of Onumah et al. (2010), the photoperiod recommended for seed production coincided to obtain bigger growth rate where breeders under longer photoperiod exhibited higher fecundity, an extended photoperiod will increase growth rate without affecting other performance traits (egg qualities and fecundity).
In this experiment it is apparent that photoperiod length exerted a positive effect on tilapia growth. It is also apparent that the same beneficial effect of photoperiod was exerted on different studied aspects of reproduction in tilapia. This means that photoperiod is adequate to maintain both the growth and reproductive capacity of these fish for the duration of the experiment. Although, in some species, the positive effect of long photoperiod is attributed to suppressed sexual maturation of the fish, leading to the greater proportion of energy directed towards somatic rather than gonadal development (Rodriguez et al., 2001), this is not consistent with the present study probably because the conditions under which these studies were carried out are different. Photoperiod exerts its influence on reproduction in fish by affecting the brain-pituitary-gonadal axis (Bromage et al., 2001). In brief, photoperiod manipulation brings about changes in gonadotrophic releasing hormone $(\mathrm{GnRH})$, and pituitary and plasma FSH (GtH I) and LH (GtH II) (Amano et al., 1994; Davies et al., 1995, 1999). Furthermore, Amano et al. (2000) reported that melatonin is one of the factors that mediated the photoperiodic signals in the control of gonadal development in Masu salmon (Oncorhynchus masou), and these changes in photoperiod are transduced by the melatonin rhythms which transfer this information to the brain-pituitary-gonadal axis. Bromage et al. $(1995,2001)$ reported that melatonin levels are strongly correlated with photoperiod manipulation in salmonids resulting in the advance or delay of spawning time, suggesting that melatonin works as a regulator in reproductive behavior. (Falcon et al., 1996) also mentioned that the pineal organ of fish, through its $24 \mathrm{hr}$ rhythmic release of melatonin, acts as a transducer of photoperiod, influencing different physiological functions such as reproduction and growth.

The results in Tables 2, 3, 4, 5 and 6 showed significant improvement in reproductive performance with exposure to longer photoperiod (18 hours light and 6 hours dark) comparing with other light schedules. Biswas et al. (2005) showed an effect of photoperiod manipulation on reproductive parameters of fecundity, gamete quality, offspring viability 
and overall reproductive process.

The Present work demonstrated a positive effect of longer day length (181 : 6 D) regimethe spawning periodicity of Nile tilapia females. These results are in agreement with Use of photoperiod manipulation to alter the incidence of sexual maturation and the time of spawning has been reported for a number of species (Duston et al., 2003; Imsland et al., 2003). Mendoza et al. (2014) found significantly larger eggs under normal day length (12 L: 12 D). However, (Ridha and Cruz, 2000) found that fish reared under long day length (18 L: 6 D) exhibited higher total fecundity and relative fecundity, with a reduction in inter-spawnintervals. Results are in consistency with the present work (Table 6) the length of the interspawning-interval (ISI) in tilapia can be influenced by many diverse factors: light intensity (Hyder, 1970) and 'robbing' of eggs from mouth-brooding parents (Siraj et al., 1983). Ridha and Cruz (2000) also suggested that the rapid removal of eggs from actively brooding females might have helped to reduce the ISI. Egg robbing is time consuming and labour intensive and may therefore only be a useful contribution to broodstock management at a very intensive commercial scale.

In this study, Tables (7-8) long photoperiod increased significantly $(\mathrm{p}>0.05)$ testosterone in males and estradiol in females. These results agreed with Fostier et al., (1983). High concentrations of this steroid in the blood plasma of male fishes and low amounts in the blood of females suggest that 11-ketotestosterone is mainly a male-specific hormone in fishes. Winkler and Wade (1998) reported that testosterone continues to increase in fish exposed to the $6 \mathrm{~L}$ : $6 \mathrm{D}$ photoperiod possibly indicating a reduction in the aromatase (a membrane-bound enzyme which is responsible for the conversion of testosterone to 17B-estradiol) activity. Mola and Hrachya (2015) revealed that higher testosterone and 11-ketotestosterone levels in males allowed female individuals to be detected for further farming up to the stage IV of gonad development, i.e., caviar production. The contribution of vitellogenin sequestration to oocyte growth is well recognized (Tyler and Sumpter, 1996) as is the role of E2 in stimulating vitellogenesis (Specker et al., 1994).
Testosterone levels in fish decreased in plasma due to exposure to xenoestrogens, and high E2 levels, presumably due to a feedback inhibition in steroids synthesis. Ankley (1998), also reported that estrogen agonists can interfere with the feedback inhibition synthesis of E2, leading to increased steroidogenesis and increased E2 levels. Lee et al. (1999) suggested that sex hormones play important role in maintenance of germ cells in the gonad. The Present results agree with these findings that circulating sex hormone levels are positively correlated with germ cell health. Hypothalamus-pituitary-gonad axis regulates reproduction in many vertebrates. Gonadotropin-releasing hormone (GnRH) controls the release of pituitary gonadotropins (GTHs) and the GTHs ultimately control production of sex steroids in the gonad.

In conclusion, this study has shown that photoperiodic manipulation appears to be a reliable and powerful tool for tilapia brood stock management. Further research is needed to fully understand how photoperiod imparts such a powerful effect upon tilapia reproduction. Particular areas of concern include the effects of 'biological' and 'reproductive' age, the precise effects of light intensity, the possible interactions of photoperiod and temperature, and how photoperiod/light intensity might influence the reproductive endocrinology of tilapia, and thus affect the dynamics of ovarian development.

\section{REFERENCES}

Ali, M.A.M. and A.M.I. El-Feky (2013). Effect of different photoperiods on growth performance, survival rate and skin colour of Nile tilapia fingerlings. Egypt. J. Anim. Prod., 50 (3) :186 -192

Amano, M., M. Ligo, I. Kazumasa, S. Kitamura, H. Yamada and K. Yamamori (2000). Roles of melatonin in gonadal maturation of underyearling precocious male Masu salmon. Gen. and Comp. Endocrinol., 120: 190-197.

Amano, M., N. Okumoto, S. Kitamura, K. Ikuta, Y. Suzuki and K. Aida (1994). Salmon gonadotropin-releasinghormone and gonadotropin are involved in precocious maturation induced by photoperiod manipulation in underyearling male Masu salmon, Oncorhynchus 
masou. Gen. and Comp. Endocrinol., 95 : $368-373$.

Ankley, G. (1998). Overview of a workshop on screening methods for detecting potential (anti-) estrogenic / androgenic chemicals in wildlife. Environ. Toxicol. Chem., 17 (1) : 68 $-87$.

Ballarin, J.D. and J.D. Hatton (1979). Tilapia: A Guide to their Biology and Culture in Africa. Stirling Univ.

Bhujel, R.C. (2000). A review of strategies for the management of Nile tilapia (Oreochromis niloticus) broodfish in seed production systems, especially hapa-based systems. Aquac., 181, 37-59.

Biswas, A.K., M. Seoka, K. Ueno, A.S.K. Yong, B.K. Biswas, Y.S. Kim, K. Takii and H. Kumai (2008). Growth performance and physiological responses in striped knifejaw, Oplegnathus fasciatus, held under different photoperiods. Aquacu., 279: 42-46.

Biswas, A.K., T. Morita, G. Yoshizaki, M. Maita and T. Takeuchi (2005). Control of reproduction in Nile tilapia Oreochromis niloticus L. by photoperiod manipulation. Aquac., 243: 229-239.

Boeuf, G. and P.L. Le Bail (1999). Does light have an influence on fish growth? Aquac., 177: 129-152.

Bromage, N., M. Porter and C. Randall (2001). The environmental regulation of maturation in farmed fin fish with special references to the role of photoperiod and melatonin. Aquac., 197 : 63- 98.

Bromage, N.R., C.F. Randall, M.J.R. Porter and B. Davies (1995). How do photoperiod, the pineal gland, mela-tonin, and circannual rhythms interact to co-ordinate seasonal reproduction in salmonid fish? In: Goetz, F.W., Thomas, P. (Eds.), Proc. Fifth Int., Symposium on the Reproductive Physiolo of Fish.Univ., Texas Publications, Austin, USA, 164- 166.

Campos-Mendoza, A., B.J. McAndrew, K. Coward and N. Bromage (2004). Reproductive response of Nile tilapia (Oreochromis niloticus) to photoperiod manipulation; effects on spawning periodicity, fecundity and egg size. Aquac., 231 : 299-313.

Chen, A., J.J. Bookstein and D.R. Meldrum (1991). Diagnosis of a testosterone. To. Ch., 12 (2):160-177.

Coward, K. and N.R. Bromage (1999). Spawning periodicity, fecundity and egg size in laboratory-held stocks of substrate-spawning tilapiine, Tilapia zilli (Gervais). Aquac., 171: 251-267.

Coward, K. and N.R. Bromage (2000). Reproductive physiology of female Tilapia broodstock. Rev. in Fish Biol. and Fish., 10 : $1-25$.

Coward, K., N.R. Bromage and D.C. Little (1998). Inhibition of spawning and associated suppression of sex steroid levels during confinement in the substratespawning Tilapia zillii. J. Fish Biol., 52 : 152-165.

Cruz, E.M.V. and C.L. Brown (2009). Influence of the photoperiod on growth rate and insulin-lik growth factor-I gene expression in Nile tilapia Oreochromis niloticus. J. Biol., 75: 130-141.

Davies, B., N.R. Bromage and P. Swanson (1999). The brain - pituitary - gonadal axis of female rainbow trout Oncorhynchus mykiss: effects of photoperiod manipulation. Gen. and Comp. Endocrinol. 115, 155-166.

Davies, B., P. Swanson and N.R. Bromage (1995). The effects of photoperiod and temperature on serum Gth I, Gth II and the timing of maturation in the female rainbow trout. In: Goetz, F.W., Thomas, P. (Eds.), Proc. of $5^{\text {th }}$ Int. Symp. on the Reprod. Physiol. Fish. Univ., Texas Pub., Austin, USA, 185.

Duncan, D.B. (1955). Multiple range and multiple F-test. Biometrics, 11: 1-42.

Duston, J., T. Astatkie and P.F. MacIsaac (2003). Long-to-short photoperiod in winter halves the incidence of sexual maturity. Aquac., 221: 567-580.

Dytham, C. (1999). Choosing and Using Statistics: A Biologist's Guide.

El-Sayed, A.F. and M. Kawanna (2004). Effects 
of photoperiod on the performance of farmed Nile tilapia Oreochromis niloticus: I. Growth, feed utilization efficiency and survival of fry and fingerlings. Aquac., 231, 393- 402.

Elsbaay, A.M. (2013). Effects of photoperiod and different artificial light colors on Nile tilapia growth rate iosr j. Agricu., and Vete., Sci., (iosr-javs) e-issn: 2319-2380, p-issn: 2319-2372. 3 (3) : 05-12

Emit, L., I. Etcheri and O. Umoren (1989). Aspects of the Reproductive Biology of Tilapia guineensi in Editas Pond, Nigeria”. Rev. Zool. Afr. J. Zool., 103: 127-134.

Eyeson, K.N. (1983). Stunting and Reproduction in Pond-reared Sarotherodon melanotheron. Aquac., 31: 257-267.

Falcon J., M. Molina-Borja and J.P. Collin and S. Oaknin (1996). Age-related Changes in 2Iodomelatonin Binding Sites in the Brain of Sea Breams (Sparus auratus)”. Fish Physiol. Biochem., 15 : 401 - 411.

Fostier, A., B. Jalabert, R. Billard, B. Breton and Y. Zohar (1983). The gonadal steroidogenesis. In: Hoar WS, Randall DJ, Donaldson EM (Eds) Fish Physiol., Acad., New York, 277372

Gines, R., J.M. Afonso, A. Argüello, M.J. Zamorano and J.L. Lopez (2004). The effects of long-day photoperiod on growth, body composition and skin colour in immature gilthead sea bream (Sparus aurata L.). Aquac., Res., 35: 1207-1212.

Gines, R., J.M. Afonso, A. Argüello, M.J. Zamorano and J.L. Lopez (2003). Growth in adult gilthead sea bream (Sparus aurata L.)

Longalong, F.M., A.E. Eknath and H.B. Bentsen (1999). Response to bi- directional selection for frequency of early maturing females in Nile tilapia (Oreochromis niloticus). Aquac., $178: 13-25$.

Lowe-McConnell, R.H. (1979). Ecological Aspects of Seasonality in Fishes of Tropical Waters”. In: Fish Phenology: Anabolic Adaptiveness in Teleosts, (P.J. Miller, Ed.). London: Acad. Press, Symposia of the Zool. Soc. London, 44 : 219-241. as a result of interference in sexual maturation by different photoperiod regimes. Aquac., Res., 34 : 73-83.

Gore-langton, R.E., J.L. Gómez-Márquez, B. Peña-Mendoza, I.H. Salgado-Ugarte and and D.T. Armstrong (1988). Follicular steroidogenesis comp endocrinol, 86 (4): 435-443.

Hallaraker, H., A. Folkvord and S.O. Stefansson (1995). Growth of juvenile halibut (Hippoglossus hippoglossus) related to temperature, day length and feeding regime. Neth. J. Sea Res., 34 : 139- 147.

Hyder, M. (1970). Gonadal and reproductive patterns in Tilapia leucosticta (Teleostei Cichlidae) in an equatorial lake, Lake Naivasha (Kenya). J. Zool., London, 162 : 179- 195.

Imsland, A.K., M. Dragsnes and S.O. Stefansson (2003). Exposure to continuous light inhibits maturation in turbot (Scophthalmus maximus). Aquac. 219, 911 - 919. Proc. 7. Int. Cent. Living Aquat. Res., Manag., Manila, Philippines: 129-140.

Krishen, J.R., S. Sunil and R.H. Mohammad (2009). Impact of Rising Feed Ingredient Prices on Aquafeeds and Aquaculture Production. No. 541, Food and Agric. Organiz. of the United Nat. (FAO), Rome, Italy

Lee, K.H., A. Yamaguchia, H. Rashida, K. Kadomurab, S. Yasumotob and $\mathrm{M}$. Matsuyamaa (1999). Germ cell degeneration in high-temperature treated Pufferfish, Takifugu rubripes. Sexual Develop., 3 : 225232.

Lutz, C.G., P. Sambidi and R.W. Harrison (2003). Tilapia industry profile. Agricultural Marketing Resource Center, Ag MRC, Iowa State University, USA. (http://test. agmrc. org/aquaculture/profiles/tilapia profiles. pdf). September 2003.

Mendoza, M.T., R. Vieira-Lanero and F. Cobo (2014). More complexity does not always mean more accuracy: the case of IBMWP and METI in NW Spain. Ecohydrol. DOI: 10.1002/eco.1528. 
Mola, A.E. and G.H. Hrachya (2015). Measurements of serum steroid hormones (testosterone, 11-ketotestosterone, and $17 \beta$ estradiol) in farmed great sturgeon. Comp. Clin. Pathol., 24:509-513.

Onumah, E.E., S. Wessels, N. Wildenhayn, Schwark G.H. and Brümmer B. (2010). Stocking density and photoperiod manipulation in relation to Estradiol profile to enhance spawning activity in female Nile tilapia. Turk. J. Fish. Aquat. Sci., 10: 463470

Rad, F., S. Bozaoglu, S. Ergene Gozukara, A. Karahan and G. Kurt (2006). Effects of different long-day photoperiods on somatic growth and gonadal development in Nile Tilapia (Oreochromis niloticus L.). Aquac., 255: 292-300.

Ridha, M.T. and E.M. Cruz (2000). Effect of light intensity and photoperiod on Nile Tilapia Oreochromis niloticus L. seed production. Aquac., Res., 31: 609-617

Rodriguez, L., S. Zanuy and M. Carrillo (2001). Influence of day length on the age at first maturity and somatic growth in male sea bass (Dicentrarchus labrax L.). Aquac., 196 : 159-175.

Sawhney, S. and R. Gandotra (2010). Effects of photoperiods on growth, feed conversion efficiency, and survival of fry and fingerlings of Mahseer, Tor putitora (Hamilton). Isr. J. Aquac.-Bamidgeh, 62: 266-271.

Siraj, S.S., R.O. Smitherman, S. Castillo-Gallusser and R.A. Dunham (1983). Reproductive traits for three year classes of Tilapia nilotica and maternal effects on their progeny. In:
Fishelson, L., Yaron, Z. (Eds.), Proc. of the Symposium on Tilapia in Aquacu., Tel Aviv Univ., Nazareth, Israel, 210- 218.

Soto-Zarazúa, M.G., G. Herrera-Ruiz, E. RicoGarcía, M. Toledano-Ayala, R. PenicheVera, R. Ocampo-Velázquez and R.G. Guevara-González (2010). Development of efficient recirculation system for Tilapia (Oreochromis niloticus) culture using low cost materials. Afr J. Biotechnol., 9: 52035211.

Specker, J.L., C.V. Sullivan, K.G. Davey, R.E. Peter and S.S. Tobe (1994). Vitellogenesis in fish's status and perspectives Perspectives in Comparative Endocrinology. Nat. Res. Coun. of Canada, Ottawa.

Turner, G.F. and R.L. Robinson (2000). Reproductive Biology, Mating Systems and Parental Care. In: Beveridge, M.C.M., MCAndrew, B. J. (Eds.), Tilapias: Biology and Exploitation. Kluwer Acad. Pub., Netherlands, 505.

Tyler, C.R. and J.P. Sumpter (1996). Oocyte growth and development in teleosts fish. Rev. Fish Biol. Fish., 6 : 287-318.

Winkler S.M. and J. Wade (1998). Aromatase activity and the regulation of sexual behaviors in the green anole lizard. Physiol. Behav., 64 : 723-731.

Yosef, S. (2009). Farming the aquatic chicken improve Tilapia in the Philippines. In: Millions Fed: Proven Successes in Agricultural Development,. Spielman, D. J. and Pandya-Lorch, R. (eds.). Int. Food Policy Res. Inst., Washington DC, USA, 125-130. 
تأثير استخلام الفترات الضوئية على النمو ويعض الأنثطة التناسلية في أسماك البلطي النيلي

$$
\begin{aligned}
& \text { نور هان حامد احمد' ـ احمد حسن دعادر' - عبد الحليم على الدروانى' }
\end{aligned}
$$

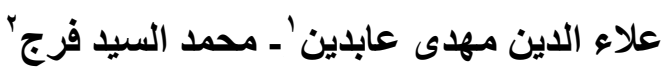

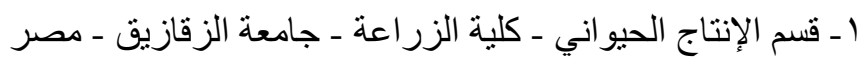

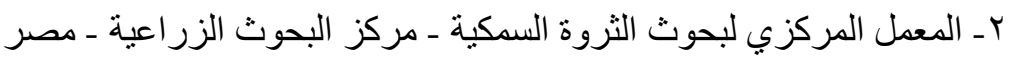

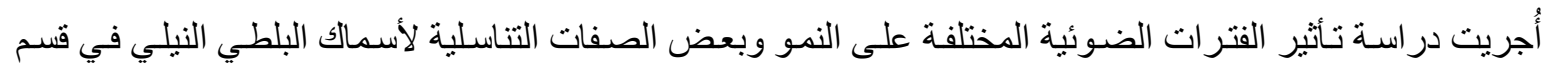

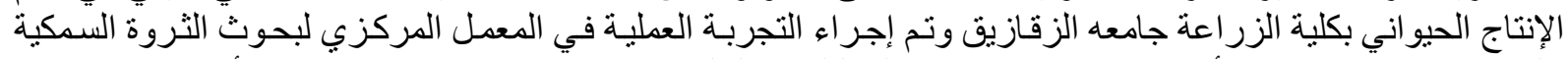

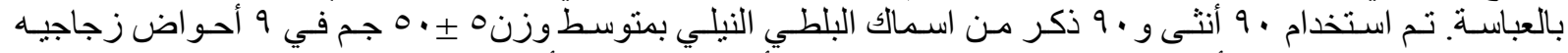

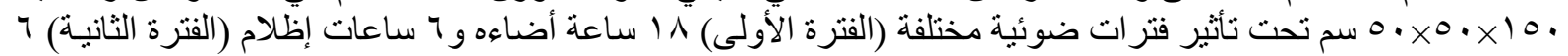

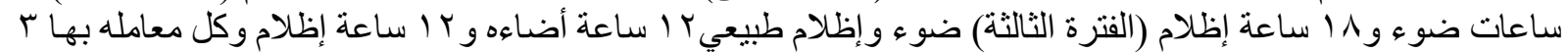

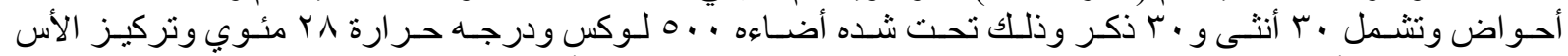

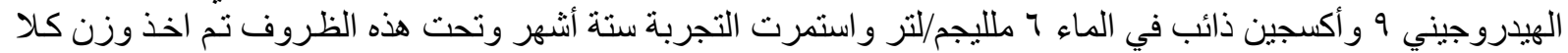

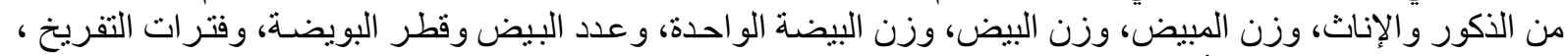

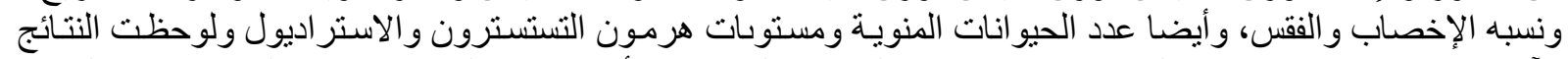

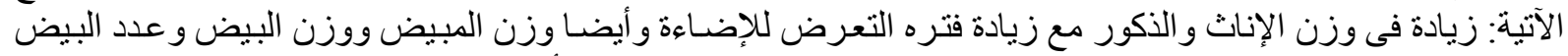

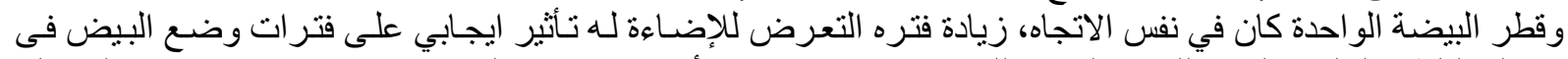

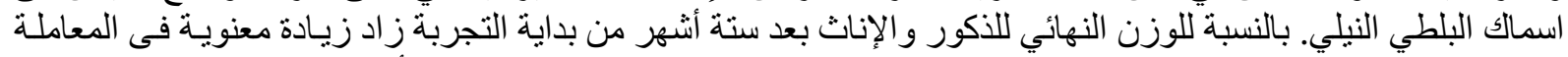

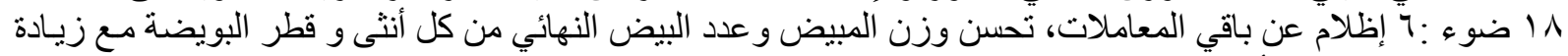

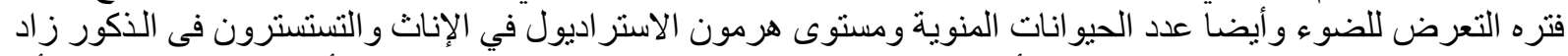

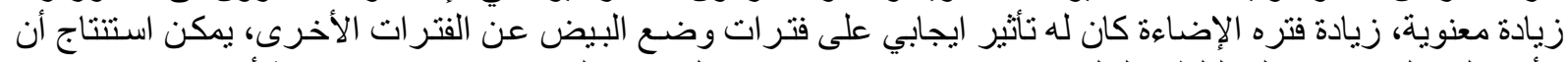

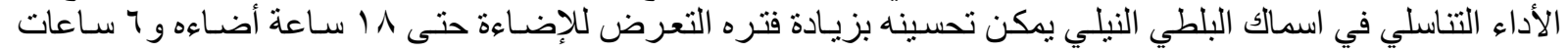

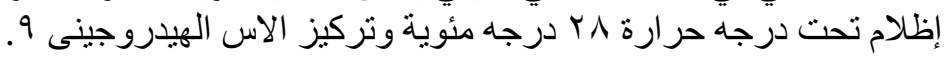

